\title{
Communication
}

[Comunicação]

\section{Ovarian follicular dynamic and plasma progesterone concentration in Alpine goats on the breeding season}

\author{
[Dinâmica folicular ovariana e concentração plasmática de progesterona em cabras \\ Alpinas durante a estação reprodutiva] \\ N.G. Alves ${ }^{1}$, C.A.A. Torres ${ }^{2}$, J.D. Guimarães ${ }^{2}$, E.A. Moraes ${ }^{3}$, \\ P.B. Costa $a^{4}$ D.R. Silva \\ ${ }^{1}$ Universidade Federal de Lavras - Lavras, MG \\ ${ }^{2}$ Universidade Federal de Viçosa - Viçosa, MG \\ ${ }^{3}$ Universidade Federal do Vale do São Francisco - Petrolina, PE \\ ${ }^{4}$ Universidade Estadual do Oeste do Paraná - Marechal Cândido Rondon, PR \\ ${ }^{5}$ Aluna de pós-graduação - Universidade Federal de Lavras - Lavras, MG
}

The average length of the normal estrous cycle in goats is 21 days, and it can vary between 18 to 22 days, depending on the breed and reproductive stage (Jainudeen et al., 2000). The estrous cycle is divided in two phases: the follicular phase and the luteal phase. According to Fatet et al. (2011), the follicular phase corresponds to the wave of follicle development providing the ovulatory follicle and involves maturation of gonadotropin-dependent follicles until ovulation. During the follicular phase, FSH secreted by the pituitary gland stimulates follicular growth. The luteal phase begins at the ovulation and it is characterized by the progesterone dominance, which is produced by the corpus luteum (CL). The rise of the progesterone concentration suppresses the pulsatile LH secretion and follicular growth, but progesterone has no physiological role in the regulation of FSH secretion (Suganuma et al., 2007). At the end of the luteal phase, 16-18 days after estrus, prostaglandin $\mathrm{F}_{2 \alpha}$ secreted by the non-gravid uterus induces the $\mathrm{CL}$ regressioncalled luteolysis- and it decreases progesterone secretion (Fatet et al., 2011). However, the occurrence of short length estrous cycles (4 to 12 days) or long length estrous cycles (>25 days) has been considered a normal physiologic phenomenon (Camp et al., 1983, Baril et al., 1993). Short length estrous cycles are characterized by early regression of the CL (Camp et. al., 1983). Long length estrous cycles are associated with continued development of two or three follicular waves after luteolysis had occurred and failure of ovulation of the ovulatory-sized follicles ( 8 to $12 \mathrm{~mm}$ ) before ovulation finally occurred (Ginther and Kot, 1994). The frequency of short cycles increases when ovulation is induced either just before or during breeding season and can be modulated by environmental factors such as photoperiod and nutrition (Fatet et al., 2011). The objective of this communication is to report the ovarian follicular dynamic and the plasma progesterone concentration on irregular length estrous cycles of Alpine goats during the breeding season.

The experiment was conducted during the breeding season from the beginning of fall to winter, during the months of March until June, in the Goat Unit of the Department of Animal Sciences at the Federal University of Viçosa $\left(20^{\circ} 45^{\prime} 20^{\prime \prime} \mathrm{S}\right.$ of latitude and $42^{\circ} 52^{\prime} 40^{\prime \prime} \mathrm{WG}$ of longitude), Brazil. Animal experimental procedures were approved and performed in accordance with the Animal Care Guidelines of Federal University of Viçosa (Protocol number 1675). Twenty-nine Alpine goats, non-pregnant, non-lactating, nulliparous, primiparous and multiparous, with (mean \pm standard deviation) $50.38 \pm 8.96 \mathrm{~kg}$ of body weight and $35.20 \pm 16.80$ months of age were used. The animals were kept confined in four collective pens (maximum of eight goats per pen) through all the study and fed twice a day with diet based on corn silage and

Recebido em 17 de fevereiro de 2017

Aceito em 18 de junho de 2018

E-mail: nadja@dzo.ufla.br 
concentrate (corn grain ground, soybean meal, urea and limestone). The offered diet quantity was adjusted daily to allow a minimum of $5 \%$ of leftovers. Water and mineral were offered $a d$ libitum.

Estrus detection was performed by a vasectomized male in each pen twice daily, at 7a.m. and 4p.m. for 15 minutes each. Goats in estrus remained immobile to mounting. The estrous cycle was defined as the number of days between two consecutive estrus.

The follicular dynamic was monitored daily by transrectal ultrasonography during one, two or three consecutive interovulatory periods for each goat, in a total of forty-seven estrous cycles. Transrectal ultrasonography of the ovaries was performed, by a single operator, daily from the day of estrus. The examinations were performed as described by Ginther and Kot (1994) using a real-time B-mode ultrasound scanner equipped with a $5.0 \mathrm{MHz}$ linear array transducer (Aloka SSD-500, Aloka Co. Ltd, Tokyo, Japan). All follicles $\geq 5 \mathrm{~mm}$ of diameter of each ovary were measured, while the diameters of follicles of 3 and $4 \mathrm{~mm}$ were estimated. The diameter of follicles $\geq 5 \mathrm{~mm}$ was determined by the average of its two largest diameters. The 3 and $4 \mathrm{~mm}$ follicles had their diameters estimated in realtime to prevent loss of identity of follicles during the frequent continuous freezing of images. The location of follicles was sketched on an ovarian map relative to each other and to the CL. Each follicle $\geq 5 \mathrm{~mm}$ was identified by a letter code in the sketch, which was maintained for as long as the follicle was identifiable. After recording locations and diameters, the sketch was compared to the sketch from the previous day. Follicular diameter data were plotted in graphs that showed the profile of growth and regression for each follicle.

A follicular wave was defined as a group of follicles which grew at the same time and which gave rise to one or more follicles $\geq 5 \mathrm{~mm}$ in diameter (Castro et al., 1999). Day of emergence of the wave was the day of emergence of the largest follicle of that wave, and more than one day was allowed for all the follicles of a wave to emerge (Ginther and Kot, 1994). The day of emergence of the largest follicle was the day that this follicle was $3 \mathrm{~mm}$ in diameter followed by an increase in diameter for $\geq 4 \mathrm{~mm}$ on the following day. When a follicle was first detected at $\geq 4 \mathrm{~mm}$ diameter the day of emergence was retrospectively determined, considering a growth rate of $1 \mathrm{~mm} /$ day. The end of wave was the day in which the last follicle in regression of that wave reached $3 \mathrm{~mm}$. The length of a follicular wave was the number of days between its emergence and end. Interwave interval was the number of days between the emergence of two successive waves. Growth phase of the largest follicle was the time taken by that follicle to grow from $3 \mathrm{~mm}$ in diameter to its maximum diameter. Growth rate $(\mathrm{mm} /$ day $)$ of a follicle was calculated by determining the increase of diameter from day of emergence until day of maximum diameter and dividing this by the number of days (Castro et al., 1999).

Ovulation was determined by the disappearance of follicles $\geq 5 \mathrm{~mm}$ and subsequent detection of a CL. The onset of luteal regression was defined as the first day that the area of CL showed progressive reduction. The number of days from ovulation to onset of luteolysis and this to next ovulation were used to define the follicular and luteal phases, respectively (Ginther and Kot, 1994). The interovulatory interval was defined as the number of days between two consecutive ovulations and was used to define the length of the estrous cycle. When two or three ovulations occurred in the same interovulatory interval, but on different days, the day of the first ovulation was considered the last day of that period.

For progesterone analysis, blood samples were collected by jugular vein puncture on the estrus day (Day 0) and on days three, seven, 11, 15 and 19 after estrus. Additional blood samples were collected at $25^{\text {th }}$ day and at weekly intervals after the $25^{\text {th }}$ day from goats that manifested long length estrous cycles. Plasma progesterone concentration was determined by solid phase radioimmunoassay (Coat-a-count progesterone kit, DPC, Diagnostic Products Co., Los Angeles, CA, USA). The assay sensitivity was $0.02 \mathrm{ng} / \mathrm{mL}$. Descriptive statistics of ovarian follicular dynamics and plasma progesterone concentration data is presented.

Forty-seven estrous cycle were followed, and from those $28(59.57 \%)$ were of normal length (17 to 25 days), seven $(14.89 \%)$ of short length ( $<17$ days) and twelve $(25.53 \%)$ of long length ( $>25$ days).The short length estrous cycles had 
(mean \pm standard deviation) $6.14 \pm 0.69$ days, with only one follicular wave, which emerged on day $0.43 \pm 1.13$ and had $5.71 \pm 1.25$ in length. The maximum diameters of the largest and the second largest follicles were $8.5 \pm 1.0$ and $6.6 \pm 1.1 \mathrm{~mm}$, respectively. The largest follicle emerged on day $0.43 \pm 1.13$ and grew for $4.86 \pm 1.77$ days, reaching maximum diameter on day $5.29 \pm 1.70$ of the estrous cycle, presenting growth rate of $1.30 \pm 0.65 \mathrm{~mm}$-day. In only one of the goats, ovulation was not detected throughout ultrasonography. In the other six goats, $1.50 \pm 0.55$ ovulations were observed and the ovulatory follicles measured $7.6 \pm 1.1 \mathrm{~mm}$. The plasma progesterone concentration was always inferior to $1 \mathrm{ng} / \mathrm{mL}$ in all goats with short length estrous cycles.

The long length estrous cycles had between 26 and 79 days, with two to nine follicular waves and, in its majority $(83.33 \%)$, were manifested in the transition period between anestrous to breeding season. Three goats did not have ovulation detected by ultrasonography, which was confirmed through the analysis of the plasma progesterone concentration that was always lower than $1 \mathrm{ng} / \mathrm{mL}$. In these animals, the estrous cycle had lengths of 28,48 or 55 days, with five, seven or nine follicular waves, respectively. In one goat, the ovarian activity was characterized by the occurrence of four follicular waves during 35 days and by the persistence of the CL, which resulted in elevated plasma progesterone concentration (> $4 \mathrm{ng} / \mathrm{mL}$ ) until day 30 of the estrous cycle. Two goats developed pseudo-pregnancy and received $125 \mu \mathrm{g}$ of cloprostenol (Ciosin, Intervet Schering) via i.m. These goats presented persistent CL, and the follicular growth occurred in six and eight waves, in the interval of 53 and 45 days, respectively. In the six other goats that also manifested long length estrous cycles, the length of the luteal phase was similar to the observed in normal length estrous cycles, but the follicular phase was prolonged in five goats (nine to 60 days). In general, the ovarian activity was characterized by the continuous development of follicular waves after luteolysis has happened and the failure in the ovulation of potentially ovulatory follicles. In this group of goats, the maximum progesterone plasma concentration of $6.32 \pm 1.33 \mathrm{ng} / \mathrm{mL}$ occurred on day 11 , followed by reduction to $3.21 \pm 2.53 \mathrm{ng} / \mathrm{mL}$ on day 19 and the maintenance of values lower than $1 \mathrm{ng} / \mathrm{mL}$ until the subsequent ovulation. The number of follicular waves, the interestrus interval and interovulatory period, the number of ovulations and the length of the follicular and luteal phase in all goats that had long length estrous cycles are presented in Table 1. Additionally, representative profiles of plasma progesterone concentration in goats that had persistent CL, pseudo-pregnancy or luteal phase length within the normal range are presented in Figure 1 and B-mode ultrasonography images of the uterus and ovaries are presented in Figure 2.

In this study, short length estrous cycles occurred during the reproductive season. Furthermore, the plasma progesterone concentration was always lower than $1 \mathrm{ng} / \mathrm{mL}$ in all goats, suggesting that the development of luteal tissue was not appropriate. On the other hand, in Nubian Goats, Camp et al. (1983) verified that the majority $(86 \%)$ of the short length estrous cycles occurred at the beginning of the breeding season and it was characterized by the premature regression of the CL, confirmed by successive laparoscopy. The mechanisms related to the functional fail and premature regression of the CL are not well known. The follicular status immediately before ovulation can influence the secretory capacity and the functional longevity of the CL (Camp et al., 1983). In the same way, the insufficient gonadotrophic support after ovulation, when the LH pulses are essential to the development of the $\mathrm{CL}$, can be related to its premature regression, and the manifestation of short length estrous cycles (Karsch et al., 1971). According to Camp et al. (1983), the progesterone production by the $\mathrm{CL}$ of the short luteal phase can influence the resurging of the normal estrus activity during breeding season. The day of wave emergence in goats that had short length estrous cycles was similar to observed by Cruz et al. (2005) on the first follicular wave in anoestrus Anglo-Nubian and Saanen goats (-1.0 to 1.0 day). Regarding the maximum follicular diameter, these authors reported lower values (6.2 to $6.8 \mathrm{~mm}$ ) compared to observed in the present study $(8.5 \pm 1.0 \mathrm{~mm})$, which may be related to the difference in the reproductive status of the animals.

In this study, three goats had anovulatory long length estrous cycles as confirmed through the plasma progesterone concentration lower than $1 \mathrm{ng} / \mathrm{mL}$. This low progesterone concentration is similar to that observed by Cruz et al. (2005) in 
anestrous Anglo-Nubian and Saanen goats in a tropical climate, and by Nogueira et al. (2016), in anovulatory rangeland and Boer goats during the non-breeding season. As previously stated, in five goats the ovarian activity during long estrous cycle was characterized by the continuous development of follicular waves after luteolysis has happened and the failure in the ovulation of potentially ovulatory follicles. The length of the luteal phase in these goats (mean, 19 days) based on ultrasonic evaluation of CL and plasma progesterone concentration was similar to reported for normal length estrous cycles (Fatet et al., 2011). Long length estrous cycles, characterized by normal luteal phase followed by a period of basal progesterone concentration were also verified by Llewelyn $e t$ al. (1993). Similarly, Ginther and Kot (1994) reported long interovulatory intervals in Saanen goats due to prolonged follicular phases after luteolysis had occurred.

Table 1. Number of follicular waves (NW), interestrus interval (IE), interovulatory period (IOP), number of ovulations (NO) and length of the follicular and luteal phase in Alpine goats that manifested long estrous cycles

\begin{tabular}{ccccccc}
\hline Goat number & NW & IE & IOP & NO & DLP & DFP \\
\hline 1466 & 6 & 43 & 43 & 2 & 20 & 23 \\
1573 & 5 & 38 & 38 & 2 & 19 & 19 \\
1732 & 6 & 53 & 53 & 2 & 36 & 17 \\
1740 & 3 & 26 & 26 & 2 & 21 & 5 \\
1771 & 7 & 48 & 48 & - & - & 48 \\
1839 & 2 & 27 & 27 & 2 & 18 & 9 \\
1905 & 9 & 55 & 55 & - & - & 55 \\
1973 & 8 & 79 & 79 & 1 & 19 & 60 \\
1994 & 4 & 35 & 35 & 1 & 33 & 2 \\
2018 & 5 & 28 & 28 & - & - & 21 \\
2024 & 8 & 45 & 45 & 1 & 36 & 9 \\
2174 & 7 & 44 & 44 & 2 & 19 & 25
\end{tabular}

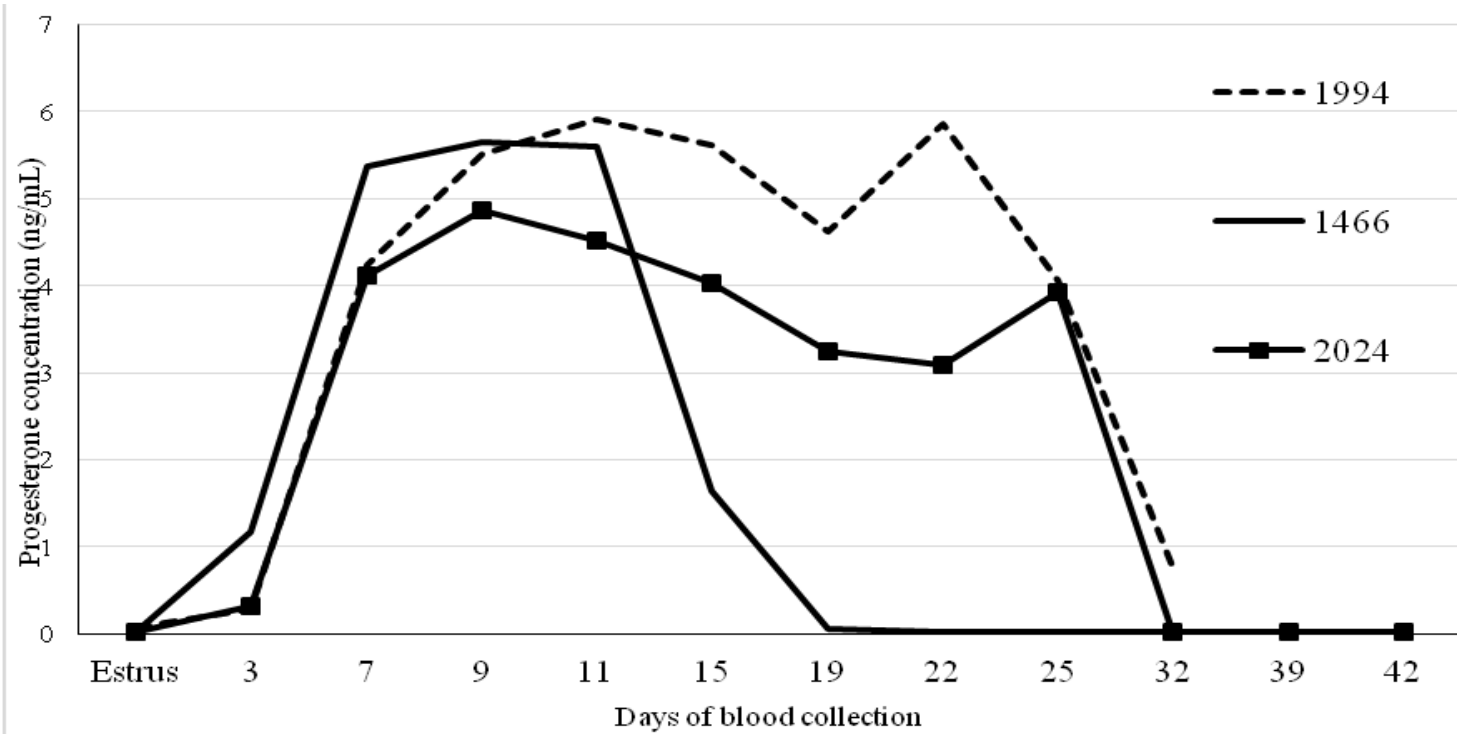

Figure 1. Plasma progesterone concentration $(\mathrm{ng} / \mathrm{mL})$ during the estrous cycle of Alpine goats that presented long length estrous cycles and had persistent CL (goat number 1994), pseudo-pregnancy (goat number 2024) or luteal phase length within the normal range (goat number 1466). Blood samples were collected on the estrus day (Day 0) and on days three, seven, 11, 15, 19 and 25 after estrus. Additional blood samples were collected weekly intervals after the $25^{\text {th }}$ day. 

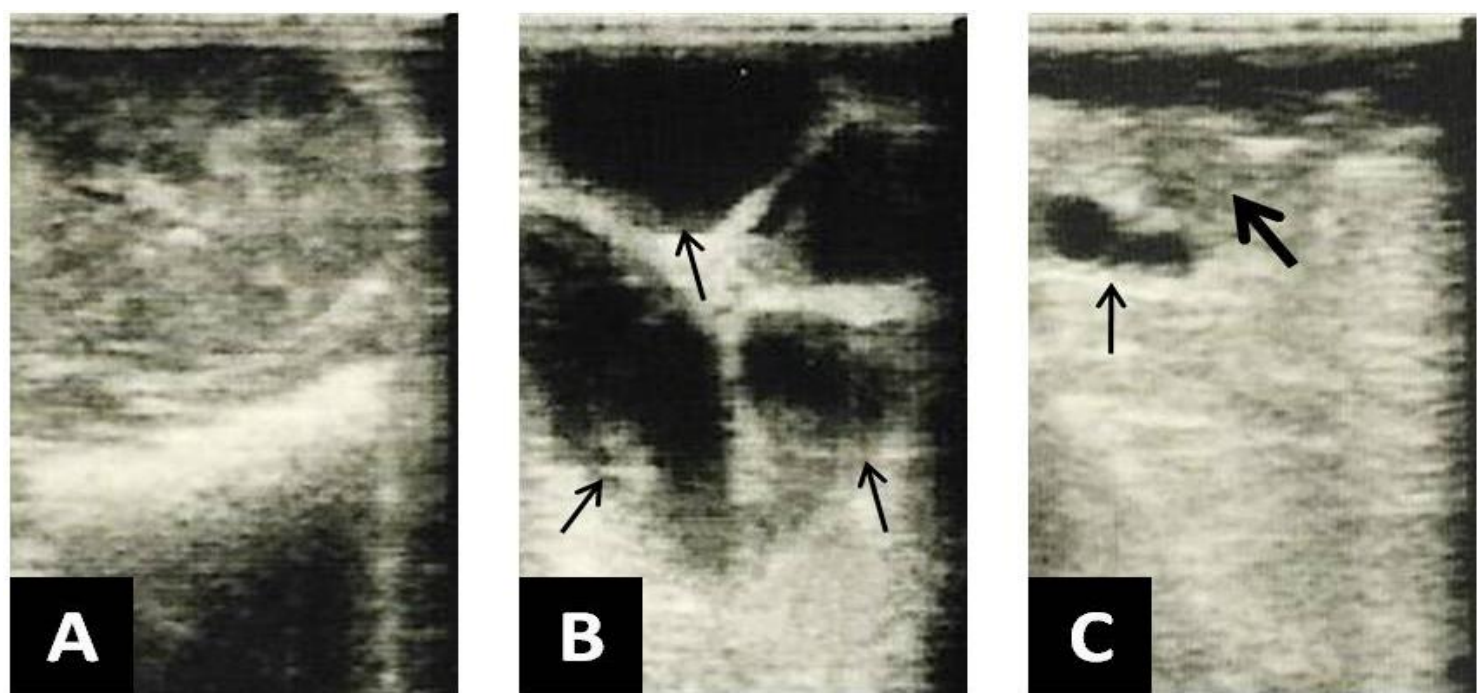

Figure 2. B-mode ultrasonography images recorded during the trial. A: Uterus of a non-pregnant animal. B: Uterus of a goat that presented pseudo-pregnancy. Parts of uterus filled with uterine fluid are presented as anechoic areas in the ultrasonography image (indicated by thin arrows). C: Ovary with follicles (anechoic area) indicated by thin arrow and corpus luteum indicated by thick arrow.

Regarding the two goats that developed pseudopregnancy, although the causes of pseudopregnancy are not totally elucidated, the inadequate release of uterine $\mathrm{PGF}_{2 \alpha}$ can be involved (Battye et al., 1988). Pseudo-pregnancy is an anestrous condition that occurs when the CL persists in the absence of a conceptus in the uterus. A characteristic feature of pseudopregnancy in the goat is the accumulation of fluid in the uterus (hydrometra). Although the diagnosis, incidence and treatment of hydrometra have been described, little is known about its etiology (Hesselink, 1993). According to Nascimento and Santos (2003), the causes of hydrometra are: obstruction of the cervix or vagina, hyperestrogenism, due to the occurrence of follicular cyst, and hymen persistence. Additionally, Taverne et al. (1988) affirmed that the phenomenon is related to the persistence of one or more CL in the ovary, resulting on predominance of progesterone, inhibiting the hypothalamic hypophyseal system and the return to the reproductive activity. It seems likely that the prevalence will be greater in herds trying to delay breeding in some does (for winter milk production) than in herds where all does are bred on the first estrus of the breeding season (Smith and Sherman, 1994).

\section{CONCLUSION}

Short length estrous cycles occurred during the breeding season and were associated to the premature regression of the CL. On the other hand, long length estrous cycles occurred in the transition between anestrous and breeding season and were associated, in its majority, to the persistence of the CL or to the occurrence of more than one follicular wave in the follicular phase. The absence of ovulation and formation of an active CL in some animals that presented long length estrous cycles is suggestive of failure in the mechanism of $\mathrm{LH}$ release, to stimulate ovulation and formation of a functional CL.

Keywords: follicular development, corpus luteum, progesterone, short estrous cycles

\section{RESUMO}

Os objetivos deste estudo foram relatar a dinâmica folicular ovariana e a concentração plasmática de progesterona durante ciclos estrais de duração irregular em cabras da raça Alpina. Vinte e nove cabras tiveram sua atividade ovariana monitorada diariamente por ultrassonografia transretal durante um, dois ou três períodos interovulatórios consecutivos. Amostras de sangue foram coletadas para análise da concentração plasmática de progesterona. Dos 47 ciclos avaliados, 28 (59,57\%) foram de duração 
normal (17 a 25 dias), sete (14,89\%) de curta duração (<17 dias) e $12(25,53 \%)$ de longa duração (>25 dias). Os ciclos estrais de curta duração tiveram 6,14 $\pm 0,69$ dias e uma onda folicular que emergiu no dia $0,43 \pm 1,13$. Os ciclos estrais de longa duração tiveram entre 26 e 79 dias, com duas a nove ondas foliculares. Os ciclos estrais de curta duração ocorreram durante a estação reprodutiva e foram associados à regressão prematura do corpo lúteo $(C L)$. Os ciclos estrais de longa duração ocorreram na transição entre o anestro e a estação reprodutiva e foram associados principalmente à persistência do CL ou à fase folicular prolongada.

Palavras-chave: desenvolvimento folicular, corpo lúteo, progesterona, ciclos estrais curtos

\section{REFERENCES}

BARIL, G.; CHEMINEAU, P.; COGNIÉ, Y. et al. Manuel de formation pour l'insémination artificielle chez les ovins et les caprins. Production et santé animales. FAO ed. n.83, 1993. Available in: <http://www.fao.org/docrep/009/t0121f/t0121f00 .htm>. Accessed in: 29 Mai. 2018.

BATTYE, K.M.; FAIRCLOUGH, R.J.; CAMERON, A.W.N.; TROUNSEN, A.D. Evidence for prostaglandin involvement in early luteal regression of the super-ovulated nanny goat (Capra hircus). J. Reprod. Fertil., v.84, p.425-430, 1988.

CAMP, J.C.; WILDT, D.E.; HOWARD, P.K. et al. Ovarian activity during normal and abnormal length estrous cycles in the goat. Biol. Reprod., v.28, p.673-681, 1983.

CASTRO, T.; RUBIANES, E.; MENCHACA, A.; RIVERO, A. Ovarian dynamics, serum estradiol and progesterone concentrations during the interovulatory interval in goats. Theriogenology, v.52, p.399-411, 1999.

CRUZ, J.F.; RONDINA, D.; FREITAS, V.J.F. Ovarian follicular dynamics during anoestrous in Anglo-Nubian and Saanen goats raised in tropical climate. Trop. Anim. Health Prod., v.37, p.395-402, 2005.

FATET, A.; PELLICER-RUBIO, M.T.; LEBOEUF, B. Reproductive cycles of goats. Anim. Reprod. Sci., v.124, p.211-219, 2011.

GINTHER, O.J.; KOT, K. Follicular dynamics during the ovulatory season in goats. Theriogenology, v.42, p.987-1001, 1994.

HESSELINK, J.W. Incidence of hydrometra in dairy goats. Vet. Rec., v.132, p.110-112, 1993.
JAINUDEEN, M.R.; WAHID, H.; HAFEZ, H.; HAFEZ, E.S.E. Sheep and goats. In: HAFEZ, B., HAFEZ, E.S.E. (Eds.). Reproduction in farm animals. Philadelphia: Lippincott Williams and Wilkins, 2000. p.172-181.

KARSCH, F.J.; ROCHE, J.F.; NOVEROSKE, J.W. Prolonged maintenance of the corpus luteum function of the ewe by continuous infusion of luteinizing hormone. Biol. Reprod., v.4, p.129-136, 1971.

LLEWELYN, C.A.; OGAA, J.S.; OBWOLO, M.J. Plasma progesterone profiles and variation in cyclic ovarian activity throughout the year in indigenous goats in Zimbabwe. Anim. Reprod. Sci., v.30, p.301-311, 1993.

NASCIMENTO, E.F.; SANTOS, R.L. Patologia da reprodução dos animais domésticos. 2.ed. Rio de Janeiro: Guanabara Koogan, 2003. p.52.

NOGUEIRA, D.M.; CAVALIERI, J.; FITZPATRICK, L.A. et al. Effect of hormonal synchronisation and/or short-term supplementation with maize on follicular dynamics and hormone profiles in goats during the non-breeding season. Anim. Reprod. Sci., v.171, p.87-97, 2016.

SMITH, M.C.; SHERMAN, D.M. Reproductive system. In: (Eds.). Goat medicine. 5.ed. Philadelphia: Lea \& Febiger, 1994. p.416-418.

SUGANUMA, C.; KUROIWA, T.; TANAKA, T.; KAMOMAE, H. Changes in the ovarian dynamics and endocrine profiles in goats treated with a progesterone antagonist during the early luteal phase of the estrous cycle. Anim. Reprod. Sci., v.101, p.285-294, 2007.

TAVERNE, M.A.M.; LAVOIR, M.C.; BEVERS, M.M. et al. Peripheral plasma prolactin and progesterone levels in pseudo pregnant goats during bromocriptine treatment. Theriogenology, v.30, p.777-783, 1988. 